UDC 338.23

DOI https://doi.org/10.32849/2663-5313/2021.8.08

Denys Koshykov,

Doctor of Law, Assistant Professor at the Department of Police Activity and Public Administration, Kharkiv National University of Internal Affairs, 27, Lev Landau avenue, Kharkiv, Ukraine, postal code 61080,Denyskoshykov@ukr.net

ORCID: orcid.org/0000-0002-0985-2897

Koshykov, Denys (2021). Promising ways to increase the effectiveness of public policy on economic security. Entrepreneurship, Economy and Law, 8, 52-58.

\title{
PROMISING WAYS TO INCREASE THE EFFECTIVENESS OF PUBLIC POLICY ON ECONOMIC SECURITY
}

Abstract. The purpose of the article is to identify promising ways to increase the effectiveness of public policy in the field of economic security. Results. The current political and economic processes in the State require systematic and well-balanced steps to improve legal, regulatory, organizational, logistical and other support for public policy on economic security. It is proved that the processes of making public policy on the economic security of Ukraine require substantial improvement and optimization regarding both the regulatory framework for the establishment and maintenance of the state economic security system and matters falling within the competence of the central executive authorities responsible for implementing economic security policy in individual sectors of social and political life. The main proposals in this area are: 1) improvement of the legal and regulatory framework for the implementation of public policy on economic security in terms of: a) improving the provisions of the Law of Ukraine "On National Security of Ukraine"; b) amending the 2020 National Security Strategy of Ukraine; c) optimizing the content of the Cybersecurity Strategy of Ukraine; 2) establishment of the Council on Economic Security under the President of Ukraine and the continuation of the Memorandum of Understanding between the Government of Ukraine and the Organisation for Economic Co-operation and Development, in particular in the areas of combating money-laundering; reforming the tax system and administration of customs duties and charges and ensuring a favourable investment climate; 3) introduction of strategic planning for economic security through the adoption of the Economic Security Strategy, Concepts and Strategies within the individual components of economic security (financial, industrial, macroeconomic, investment, foreign economy and human security); 4) development of the draft Law of Ukraine "On Economic Security of Ukraine". Conclusions. The author makes proposals to establish the Council on Economic Security under the President of Ukraine. This body should include several specialized commissions in the areas of: financial, industrial, macroeconomic, investment and innovation, foreign economy and human security.

Key words: economic security, national security, public policy, administrative legislation, efficiency assessments, efficiency, optimization.

\section{Introduction}

The current political and economic processes in the State require systematic and well-balanced steps to improve the legal, regulatory, organizational, logistical and other support for public policy on economic security. This is due to the analysis of the current legal and regulatory framework and the specificities of the activities of state bodies with powers to ensure the economic security of the State and of international legal acts and practices to counter economic offences of varying hazard.

The purpose of the article is to identify promising ways to increase the effectiveness of public policy in the field of economic security.
2. Law of Ukraine "On National Security of Ukraine"

Therefore, first, the content of existing legal and regulatory instruments that form the legal basis for the making public policy on the economic security should be analysed.

On June 21, 2018, the Law of Ukraine "On National Security of Ukraine" was adopted, the main provisions of which defined the contents of key terms, such as, "military security", "public security and order", "state security", "defence planning", "national security planning", "National Security Strategy of Ukraine", "Military Security Strategy of Ukraine", "Cybersecurity Strategy of Ukraine", and others. 
The Law stipulates that the President of Ukraine shall be in charge of national security and defence, in accordance with the Constitution, and the National Security and Defence Council shall be responsible for coordination in the fields of national security and defence.

The Law being analysed determines the powers of national security actors such as the Ministry of Defence, the Armed Forces of Ukraine, the State Special Transport Service, the Ministry of Internal Affairs and the Security Service, Intelligence agencies, the Office of State Protection, the State Special Communication and Information Protection Service, etc. (Verkhovna Rada of Ukraine, 2018).

The Law focuses on the planning in national security, its objective and principles, as well as defines the main types of state instruments on this issue, which should constitute the regulatory framework for Ukraine's national security: the National Security Strategy of Ukraine, the Comprehensive Review of the Security and Defence Sector, the Military Security Strategy of Ukraine, the Public Security and Civil Protection Strategy of Ukraine, the Defence and Industrial Development Strategy of Ukraine, the Cybersecurity Strategy of Ukraine, the National Intelligence Programme, state programmes in the fields of national security and defence, etc. (Verkhovna Rada of Ukraine, 2018).

Therefore, the relevant law of our country focuses on the security and defence sector. the organization of the activities of the Armed Forces, counter-intelligence activities, information and cyber-security of the State.

However, the above-mentioned law lacks a systematic view of economic security of the State as a fundamental element that, incidentally, forms the basis of other elements of national security, since the defence complex and the Armed Forces of Ukraine, the organization of counter-intelligence activities and the cybersecurity, etc. cannot develop without adequate material and financial support and sustainable economic indicators. Therefore, we make a proposal to improve the Law in the following areas.

First, it is necessary to clearly define the components of national security, requiring the introduction of a separate article "Sectors (Components) of National Security of Ukraine", which shall determine that these components, for example, are political security, economic security, military security, public safety, information security, environmental security, cybersecurity.

Secondly, para. 10 of article 1 and article 3 of this law define the terms "national interests of Ukraine" as the vital interests of the individual, society and the State, the implemen- tation thereof ensures the State sovereignty of Ukraine, its progressive democratic development, as well as safe living conditions and the well-being of its citizens (Verkhovna Rada of Ukraine, 2018). In particular, state sovereignty, territorial integrity and the sustainable development of the national economy, civil society and the State are among such interests.

At the same time, we argue that part 3 of article 3 of this Law should be naturally extended by defining national interests in various fields of national security. Regarding the subject matter of our study, the law should be added with a separate article "National Interests of Ukraine in the economic sector". These economic interests include: ensuring economic growth and increasing the competitiveness of Ukraine's national economy; ensuring the innovative development of the economy by involving advanced technologies, investments and applying advanced methods and forms of the regulatory mechanism for the economic sector; ensuring stability of the financial system of Ukraine; conducting balanced monetary and credit policy; maintaining the country's energy independence by supporting domestic producers and ensuring a balanced energy price policy; developing high-technology and competitive sectors of the economy, which produce high value-added products; supporting entrepreneurship and ensuring minimal state intervention in economic relations; overcoming monopoly and promoting competition; carrying out balanced fiscal and customs policies; ensuring the quality and development of human capital in all sectors of the national economy; ensuring the economic rights and freedoms of natural and legal persons by countering systematically economic crime and corruption, etc.

Therefore, the list of actors that provide the economic security of the State should include, in addition to the Government of Ukraine, specialized ministries, the State Fiscal Service, the Antimonopoly Committee, the State Financial Monitoring Service, as well as their key competencies.

A separate article of the Law of Ukraine "On National Security of Ukraine" should provide for the concept and content of economic security of the State. In particular, in this article we propose to add our author's definition of economic security as a component of Ukraine's national security, which is the status of social relations in production, distribution, exchange and consumption of goods and services that characterizes their protection and resilience to external and internal threats, guarantees the protection of national economic interests and promotes the realization of the social and economic rights and freedoms of citizens, as well as creates con- 
ditions for further development and growth of the national economy and the competitiveness of the State in the global economic environment.

This article should define the elements of economic security, such as: financial, macroeconomic, industrial, energy, foreign economy, investment and innovation, human, which in turn consists of food, social and demographic security.

3. Tasks of public policy on economic security

Furthermore, we propose that the relevant article of the Law should define the tasks of public policy on economic security, namely:

1) to improve the provisions of current Ukrainian legislation in the economic sector by developing key laws and adopting strategic programmes in the field of economic security;

2) to establish an effective institutional system to ensure the implementation of the State's economic security strategy, the identification of its key actors, the limits of their powers and the basis for cooperation and coordination;

3) to involve representatives of the business environment, specialized trade unions, representatives of small businesses and the economic scientific community in the development and implementation of economic safety programmes and measures;

4) to increase the economy's resilience to the impact of external and internal challenges and threats, to improve the investment climate in the country, the budgetary planning processes and the socio-economic development of theregions, and toimprovethefinancialsecurity system, to optimise the regulatory and tax burden;

$5)$ to develop an appropriate economic culture and financial literacy among the population;

$6)$ to introduce modern information and communication technologies into the system of economic relations in order to improve the processes of economic transactions; to minimize the risks of the parties and make it easier for the public to obtain financial and other services;

7) to ensure the harmonious integration of Ukraine into the European and world economic security environment and the development of fair and mutually advantageous economic relations with other States; as well as State participation in countering global economic threats and transnational economic crime;

8 ) to create legal and organizational grounds for citizens to exercise their economic rights and freedoms (rights to property, to entrepreneurial activities, etc.), to ensure their protection and their restoration in the event of violations;

9) to establish a fundamentally new system of control and law enforcement bodies responsible for economic security; to exclude uncharacteristic powers from the competence of existing actors of law enforcement, in particular with regard to interference in economic relations;

10) to protect adequately the information and communication infrastructure of the Ukrainian economy: payment systems, information banks, data registers, personal data of economic entities, etc.;

11) to create conditions and to adopt systematic measures against corruption, violations of anti-monopoly legislation, financial and economic crimes, especially those committed by organized criminal groups, and against money laundering.

Moreover, an appropriate step is to formulate a legislative provision regarding the responsibility of the State to control the use of economic facilities operated by foreign organizations or organizations with foreign capital, but certainly with respect for the rights and legitimate interests of such investors. In addition, it is necessary to envisage restrictions on the ownership or rights to use and manage strategic resources of Ukraine.

In addition, the focus should be on the improvement of economic security planning processes as part of national security. The Law of Ukraine "On National Security of Ukraine" indicates that the instruments of long-term planning are the National Security Strategy of Ukraine, the Military Security Strategy of Ukraine, the Public Security and Civil Protection Strategy of Ukraine, the Defence and Industrial Development Strategy of Ukraine, the Cybersecurity Strategy of Ukraine, the National Intelligence Programme. The medium-term planning instruments include other strategic instruments, security sector development programmes. Short-term planning includes the development of annual maintenance and development (activities) planning for the components of the security and defence sector (Verkhovna Rada of Ukraine, 2018). In this context, it is strange that, despite recognition of economic security as part of national security, the relevant law in no way contains provisions on strategic instruments in this field, while it stresses the importance of the Cybersecurity Strategy, the Public Order Strategy, etc. Therefore, we argue that Article 25 of the Law of Ukraine "On National Security of Ukraine" should be amended to define that Ukraine strategic planning in the field of economic security is carried out through the adoption of the National Economic Security Strategy, Concepts and Strategies within the individual components of economic security. For example, in 2012, Order № 569 of the Cabinet of Ministers of August 15, 2012 approved the Concept of ensuring national security in the financial 
sphere (Cabinet of Ministers of Ukraine, 2012), however, many of its provisions need to be rethought and improved in the light of the current state of the global economy and the functioning of national financial sector, and hence the elaboration and approval of these instruments is of relevance. Therefore, sectoral concept instruments on financial, industrial, macroeconomic, investment and innovation, energy, foreign economy and human security should be developed on the basis of the proposed National Economic Security Strategy.

With regard to the Cybersecurity Strategy, we believe that some areas for improvement in its content in terms of ensuring cybersecurity in the economic sector of the State exist. Indeed, the Strategy states that the National Bank is the entity responsible for cybersecurity in the banking sector, as well as provisions relating to general issues, in particular the improvement of the system of storage, transfer and processing of data of public registers and databases using modern information and communication technologies (including online access technologies) (President of Ukraine, 2016).

The Strategy underlines the need of training security and defence sector actors to respond to cyberattacks and cybersecurity incidents, in particular, cyber-drills for the Armed Forces of Ukraine and other actors in the security and defence sector of Ukraine, participation in such trainings as part of collective defence activities. However, many state bodies responsible for sustainable economic development, databases of State property registers, etc. are not part of the security and defence sector. At the same time, they and their information resources are threatened by cybernetic attacks. Therefore, the above-mentioned provisions of the Cybersecurity Strategy of Ukraine should be amended to read as follows: "4.4. The development of cybersecurity and defence potentials in the security and defence sector should include activities, conducted in the manner prescribed, such as trainings for security and defence actors and other State bodies responsible for individual components of national security, that possess and maintain State registers and data banks to respond to cyberattacks and cybersecurity incidents, in particular, cyber-drills of the Armed Forces of Ukraine, other actors of the security and defence sector of Ukraine, participation in such trainings as part of collective defence activities".

The adoption of the New National Security Strategy of Ukraine on 14 September 2020 was a positive step (President of Ukraine, 2020a). In accordance with the contents of this instrument, the Cabinet of Ministers of Ukraine should submit a draft Economic Security Strategy to the National Security and Defence Council of Ukraine within six months, and the Energy Security Strategy and the Food Security Strategy should be developed and approved within six months of the adoption of the document (President of Ukraine, 2020a).

Thus, we argue that at present no conceptual instruments have been approved for the implementation of public policy on State economic security. In addition, we believe that the proposals outlined regarding the content of the Law of Ukraine "On National Security of Ukraine" can become the basis of the draft Law of Ukraine "On Economic Security of Ukraine".

Next, the activities of the advisory bodies established in the State and operating within the framework of the President of Ukraine's constitutional powers should be noted.

From our perspective, the establishment of the Council of Experts on Energy Security, an advisory body to the National Security and Defence Council of Ukraine headed by the Head of State, is a positive step. For example, in the exercise of the powers conferred, the National Security and Defence Council is entitled to prepare proposals on: counteracting and neutralizing threats to Ukraine's energy security; defining conceptual approaches and areas for energy security; measures to increase the effectiveness of public policy in the fuel and energy sector; improving coordination of the activities of executive bodies in the field of energy security; identifying ways, mechanisms and means of resolving problem issues arising in the implementation of public policy in the fuel and energy sector; improving the legal and regulatory framework for the fuel and energy sector (President of Ukraine, 2020b).

Another body that should influence public policy in almost all fields of public life is the National Reform Council, a special advisory body under the President of Ukraine on strategic planning, harmonizing the introduction of a single public policy on reforms and their implementation in Ukraine.

The main tasks of the National Reform Council are as follows: 1) to define the areas and priorities of reforms aimed at the realization of national interests and the protection of constitutional human and civil rights and freedoms, and to make a unified, coordinated public policy, develop a strategy and mechanisms for introducing reforms; 2) to reach consensus on the introduction of reforms between the President of Ukraine, State authorities and civil society; 3 ) to promote coordinated implementation of reforms and to monitor their effective implementation; 4) to set priorities for regulatory support for the practical implementation of reforms (President of Ukraine, 2014). 
However, we argue that making public policy on the economic security should be carried out in a more systematic manner and while the best experts should engage in the process of reforming economic relations. Therefore, we argue that establishment a Council on Economic Security under the President of Ukraine is a topical issue. This body should include several specialized commissions in the areas as follows: finance, macroeconomy, industry, energy, foreign economy, investment and innovation, and human security.

The Council composed in such manner will enable to comprehensively implement the necessary reforms and innovations in the field of State economic security and to organize interaction between experts in the field within the framework of single coordinating body, and to advise to the President systematic steps to prevent and overcome internal and external threats in the economic sector and to promote the realization of the economic rights and freedoms of individuals and legal entities.

The tasks of the Council are: an analysis of the economic security of the State, forecasting the development of economic relations and the study of internal and external threats to economic security; the study of the status of making public policy on economic security; an analysis of the legal and regulatory framework, regulatory instruments and draft laws on issues relating to economic security of the State; preparation of proposals to the President of Ukraine on: 1) neutralization or minimization of threats to the economic security of the country; 2) improving the legal and regulatory framework for ensuring economic security; 3 ) optimizing the performance of the State's law enforcement bodies against economic crime and corruption; 4) measures aimed at enhancing the effectiveness of public policy on economic security and its individual components; 5) improving cooperation and coordination of the activities of State authorities in matters relating to economic security of the State.

Therefore, the appropriate steps in the State activity being studied should be:

- amendments to the Law of Ukraine "On the Fundamentals of State Regional Policy" in terms of defining the priority of regional economic security as a component of public policy at the meso level;

- harmonization of the provisions of the laws of Ukraine "On Local State Administrations" and "On Local Self-Government" with the Laws "On Foreign Economic Activity" and "On Transborder Cooperation" in terms of performing foreign economic functions and functions of the body of transborder cooperation.

\section{Conclusions}

By relying on research findings, the author can sum up the following:

1. The processes of making public policy on the economic security of Ukraine require substantial improvement and optimization regarding both the regulatory framework for the establishment and maintenance of the State economic security system and matters falling within the competence of the central executive authorities, responsible for implementing economic security policy in individual sectors of social and political life (Koshykov, 2020).

2 . With regard to the legal and regulatory framework, it is advisable to:

a) improve the provisions of the Law of Ukraine "On National Security of Ukraine" in terms of determining it as a separate component of national security, legislative consolidation of national interests in the field of economic security, actors that ensure them, etc.;

b) amend the 2020 National Security Strategy of Ukraine, which, in our opinion, should focus on issues of comprehensive State economic security;

c) improve the provisions of the Cybersecurity Strategy of Ukraine with regard to ensuring the information security of public administrators in the economic sector;

d) introduce strategic planning for economic security through the adoption of the Economic Security Strategy, Conceptsand Strategies within the individual components of economic security (financial, industrial, macroeconomic, investment, foreign economy and human security)

e) draft the Law of Ukraine "On Economic Security of Ukraine";

f) adopt the New Strategy for Sustainable Development of Ukraine for 2021-2026, adjusting the indicators of achievement of key objectives (parameters). The Strategy should separately identify criteria and indicators for economic security as a component of national security, not limited to defence and military affairs, as well as include criteria and indicators as defined by the UN Resolution "Transforming our World: The 2030 Agenda for Sustainable Development".

3. The Law of Ukraine "On Fundamentals of State Regional Policy" requires changes in terms of defining the priority of regional economic security as a component of public policy at the meso level. Moreover, the provisions of the laws of Ukraine "On Local State Administrations" and "On Local Self-Government" should be harmonized with the Laws "On Foreign Economic Activity" and "On Transborder Cooperation" in terms of performing foreign economic functions and functions of the body of transborder cooperation. These steps should be further harmonized with the concept of decentralization of the country. 


\section{References:}

Cabinet of Ministers of Ukraine (2012). Pro skhvalennia Kontseptsii zabezpechennia natsionalnoi bezpeky u finansovii sferi: Rozporiadzhennia Kabinetu Ministriv Ukrainy vid 15 serpnia 2012 roku № 569-p [On approval of the Concept of ensuring national security in the financial sphere: Order of the Cabinet of Ministers of Ukraine from August 15, 2012, № 569-p]. kmu.gov.ua. Retrieved from: https://zakon.rada.gov.ua/laws/show/569-2012$\% \mathrm{D} 1 \% 80 \#$ Text (in Ukrainian).

Koshykov, D.O. (2020). Administratyvno-pravovi zasady realizatsii derzhavnoi polityky u sferi zabezpechennia ekonomichnoi bezpeky derzhavy [Administrative and legal bases of realization of the public policy in the field of maintenance of economic safety of the state]. Kharkiv: Panov (in Ukrainian).

President of Ukraine (2014). Pytannia Natsionalnoi rady reform i Vykonavchoho komitetu reform: Ukaz Prezydenta Ukrainy vid 13 serpnia 2014 roku № 644/2014 [Issues of the National Council of Reforms and the Executive Committee of Reforms: Decree of the President of Ukraine from August 13, 2014, № 644/2014]. president.gov.ua. Retrieved from: https://zakon.rada.gov.ua/laws/show/644/2014\#Text (in Ukrainian).

President of Ukraine (2016). Pro rishennia Rady natsionalnoi bezpeky i oborony Ukrainy vid 27 sichnia 2016 roku "Pro Stratehiiu kiberbezpeky Ukrainy": Ukaz Prezydenta Ukrainy vid 15 bereznia 2016 roku № 96/2016 [On the decision of the National Security and Defense Council of Ukraine of January 27, 2016 "On the Cyber Security Strategy of Ukraine”: Decree of the President of Ukraine from March 15, 2016, № 96/2016]. president.gov.ua. Retrieved from: https://zakon5.rada.gov.ua/laws/show/96/2016\#Text (in Ukrainian).

President of Ukraine (2020a). Pro rishennia Rady natsionalnoi bezpeky i oborony Ukrainy vid 14 veresnia 2020 roku "Pro Stratehiiu natsionalnoi bezpeky Ukrainy": Ukaz Prezydenta Ukrainy vid 14 veresnia 2020 roku № 392/2020 [On the Decision of the National Security and Defense Council of Ukraine of September 14, 2020 "On the National Security Strategy of Ukraine": Decree of the President of Ukraine from September 14, 2020, № 392/2020]. president.gov.ua. Retrieved from: https://www.president.gov.ua/documents/3922020-35037 (in Ukrainian).

President of Ukraine (2020b). Pro zatverdzhennia Polozhennia pro Radu ekspertiv z pytan enerhetychnoi bezpeky: Ukaz Prezydenta Ukrainy vid 29 travnia 2020 roku № 206/2020 [On approval of the Regulations on the Council of Experts on Energy Security: Decree of the President of Ukraine from May 29, 2020, № 206/2020]. president.gov.ua. Retrieved from: https://www.rnbo.gov.ua/ua/Ukazy/4615.html (in Ukrainian).

Verkhovna Rada of Ukraine (2018). Pro natsionalnu bezpeku Ukrainy: Zakon Ukrainy vid 21 lypnia 2018 roku № 2469-VIII [On National Security of Ukraine: Law of Ukraine from July 21, 2018, № 2469-VIII]. rada. gov.ua. Retrieved from: https://zakon.rada.gov.ua/laws/show/2469-19 (in Ukrainian).

\section{Денис Кочиков,}

доктор юридичних наук, старший викладач кафедри полічейської діяльності та публічного адміністрування, Харківський начіональний університет внутрішніх справ, проспект Льва Ландау, 27, Харків, Україна, індекс 61080, Denyskoshykov@ukr.net

ORCID: orcid.org/0000-0002-0985-2897

\section{ПЕРСПЕКТИВНІ ШЛЯХИ ПІДВИЩЕННЯ ЕФЕКТИВНОСТІ ДЕРЖАВНОЇ ПОЛІТИКИ У СФЕРІ ЗАБЕЗПЕЧЕННЯ ЕКОНОМІЧНОЇ БЕЗПЕКИ}

Анотація. Сучасні політичні та економічні процеси, які відбуваються в державі, потребують системних і виважених кроків щодо вдосконалення нормативно-правового, організаційного, матеріально-технічного та іншого забезпечення державної політики у сфері економічної безпеки. Метою $\boldsymbol{c m a m m i} €$ визначення перспективних шляхів підвищення ефективності державної політики у сфері економічної безпеки. Результати. Аргументовано, що процеси формування й реалізації державної політики у сфері забезпечення економічної безпеки України потребують суттєвого вдосконалення та оптимізації, що стосується як нормативної бази формування й забезпечення системи економічної безпеки держави, так і питань, які належать до компетенції центральних органів виконавчої влади, що мають повноваження з реалізації політики економічної безпеки в окремих сферах суспільнополітичного життя. Основними пропозиціями в цьому напрямі $є$ такі: 1) трансформація нормативноправового забезпечення реалізації державної політики у сфері економічної безпеки в частині: а) удосконалення положень Закону України «Про національну безпеку України»; б) внесення змін до Стратегії національної безпеки України (2020 року); в) оптимізації змісту Стратегії кібербезпеки України; 2) створення при Президентові України Ради з питань забезпечення економічної безпеки, продовження дії Меморандуму про взаєморозуміння між Урядом України та Організацією економічного співробітництва, зокрема, за напрямами протидії відмиванню коштів, реформування податкової системи та системи адміністрування митних зборів і платежів, забезпечення сприятливого інвестиційного клімату; 3) запровадження стратегічного планування у сфері економічної безпеки шляхом прийняття Стратегії економічної безпеки, концепцій і стратегій у межах окремих склад- 
ників економічної безпеки (фінансової, виробничої, макроекономічної, інвестиційної, зовнішньоекономічної та гуманітарної безпеки); 4) розроблення проєкту Закону України «Про економічну безпеку України». Висновки. Запропоновано створити при Президентові України Раду з питань забезпечення економічної безпеки. У складі такого органу варто сформувати декілька профільних комісій за напрямами (зокрема, з фінансової, макроекономічної, виробничої, енергетичної, зовнішньоекономічної, інвестиційно-інноваційної та гуманітарної безпеки).

Ключові слова: економічна безпека, національна безпека, державна політика, адміністративне законодавство, оцінювання ефективності, ефективність, оптимізація.

The article was submitted 13.08.2021

The article was revised 02.09.2021

The article was accepted 21.09.2021 